Research Article

\title{
Resilience as a Mediator in Spiritual Relations and Quality of Life for Entrepreneurs
}

\author{
Merlyn Ika R.P ${ }^{1}$ \\ University of Muhammadiyah Malang
}

\author{
Hennira Rohyatin $^{2}$ \\ University of Muhammadiyah Malang
}

\author{
Latipun Latipun $^{3}$ \\ University of Muhammadiyah Malang
}

\footnotetext{
${ }^{1}$ Master Student at Department of Psychology, University of Muhammadiyah Malang. E-mail: merlynika@gmail.com

${ }^{2}$ Master Student at Department of Psychology, University of Muhammadiyah Malang. E-mail: heynirarohyatin@gmail.com

${ }^{3}$ Professor at Department of Psychology, University of Muhammadiyah Malang. E-mail: lativ_un1@yahoo.com
}

Corresponding author: Merlyn Ika R.P.

E-mail:

merlynika@gmail.com

eISSN: 2458-9675

Received: 26.06.2020

Revision: 12.10.2020

Accepted: 07.01.2021

CCopyright 2021

by Author(s)

\begin{abstract}
Everyone wants a good quality of life and also has its own standards regarding the quality of life, as well as entrepreneurs. Quality of life can include all aspects of life that can not be separated from the elements of spirituality. This study aims to determine whether there is a relationship of spirituality to the quality of life in entrepreneurs mediated by resilience. This research uses a quantitative approach. The subjects of this study were 100 entrepreneurs who were scattered in Malang, aged 20-35 years consist of Male 76 persons and female 24 persons. Sample selected from through groups of entrepreneurs in Malang with a purposive sampling method. The measuring instrument used was a questionnaire from the scale of The Daily Spiritual Experience Scale, The Quality of Life Enjoyment and Satisfaction Questionnaire - Short Form (Q-LES-Q-SF), The Connor-Davidson Resilience Scale (CD-RISC-25). Data analysis using IBM SPSS version 21 analysis techniques with PROCESS macros from Hayes. From the results of this study there is a mediating effect of resilience in the spiritual relationship with quality of life in entrepreneurs. That spirituality does not only have a direct influence on the quality of life, but also indirectly through resilience.
\end{abstract}

Keywords: Resilience, Spirituality, Quality of life. 
One strategy to exploit the potential of a country's human resources is to maximize it through entrepreneurship. Glaeser, Keer \& Keer (2013), conveyed the need for entrepreneurs as the economic drivers of the community, they play a significant role in the growth of the city. An entrepreneur is no other than to get a wage, meet their needs and to get a good quality of life. According to Ruggeri et al., (2001), good quality of life is everyone's dream and that applies to entrepreneurs. However, each person's perception of quality of life is different and has its own standards, including the ideal quality of life or as desired. According to the World Health Organization Quality of Life (WHOQOL) (1996), quality of life is an individual's perception of the position of individuals in life in accordance with the cultural context and value system adopted, where individuals live and their relationship with expectations, goals, standards set and attention from individual.

Being an entrepreneur is one of the right choices for the community and becomes an interesting and attractive thing. Lorenzini (2015) states that young people who are not working will have low life satisfaction and make it easier to get involved in protests. At this point, entrepreneurial behavior can solve one of the important issues faced by the people of Indonesia. Kasali (2010), said entrepreneurs can help increase satisfaction and quality of life and help improve the country's economy, because the more people who are capable of entrepreneurship will lead to an increase in state income. To further sharpen the problem, in this study the productive population in question is more specifically at the age of 20-35 years. This is due to the generality of the youth entrepreneur organization in Indonesia which is in the age of 20-35 (Qamariah, 2016). Likewise, the connection between quality of life and entrepreneurship is reflected in both of them being a good indicator to see the growth of the nation and the State (Bache, 2013; Grine, Fares, \& Meguellati, 2015). This is one of the reasons for this research to elaborate further about the quality of life in the entrepreneurial community, specifically those who are still in their productive age.

In addition, previous studies have found that good quality of life is the main goal for entrepreneurs (Lu \& Pan, 2009). In this study, Lu \& Pan (2009), found the factor of life satisfaction as having an influence on the quality of life of an entrepreneur. Meanwhile, according to Rogala (2014), that quality of life is related to the needs of the individual itself. A study conducted by Dash \& Kaur (2012), in India found that from the achievements obtained from entrepreneurship, it can lead to its own satisfaction with his life.

Then Sirgy (2012) explained about several important variables that have a relationship to quality of life, including objective factors and subjective factors. Objectively demographic factors, income, wealth, and macro conditions have a role in quality of life. Subjectively, values, personality, emotions, and cognition have a role in the quality of life. In this study the selection of entrepreneurial communities is an 
effort to represent an objective element of quality of life. This is because entrepreneurs have a considerable influence on the level of wealth, welfare, and income (Samli, 2009; Bache, 2013). In Sirgy's research, one of the subjective factors which is quite important is the internal values of individuals such as religion, spirituality, and life satisfaction.

Spiritual entrepreneurs are needed because some facts and research support that quality of life is supported by spirituality. Research conducted by Baker (2003), proves that spirituality contributes to quality of life. Other studies have also been conducted by Young (2012), on individuals with mental disorders who show that the positive effects of spirituality can improve the quality of life, because by getting closer to God it will reduce the stress obtained from everyday life. Spirituality is different from religion, spirituality is a broader concept that is universal and personal while religion is part of spirituality related to culture and society (McEwen, 2003). Individuals are said to have good spirituality if the individual has full, optimistic, and positive thinking (Roper, 2002). According to Delaney (2005), spirituality is a multidimensional phenomenon that produces universal experience.

However, previous studies have shown an inconsistent relationship between spirituality and quality of life. Akbar \& Hosain (2018), show that there is a non-linear relationship between spirituality and quality if life. Likewise, Cabale \& Cayetano's (2019) suggests that spiritual care does not have a direct relationship with the overall quality of life of the elderly. This description explains the reasons for spiritual research with quality of life to be interesting to study, because there are gaps in research.

Getting a good quality of life as desired can be obtained not only by increasing spirituality, but by being able to analyze yourself and survive in difficult situations. Self-analysis, namely by analyzing the strengths and weaknesses, opportunities and failures in yourself. So that you can find the strengths or weaknesses that exist in yourself. There are several entrepreneurs who have received business capital assistance but then fail and stop not continuing their business due to various obstacles (difficulty in dividing time, lack of managerial ability, difficulty in promoting, developing their business, and competition among entrepreneurs who are fast). Therefore, one of the abilities that entrepreneurs must have is resilience.

Resilience is the capacity an entrepreneur has to cope with difficult circumstances, this capacity to adapt and reflect back in adversity depending on individual resources and their interactions with the environment, Ayala Manzano (2014). Resilience is a dynamic adaptation process that is able to make entrepreneurs continue their efforts despite the many obstacles they face. If someone has low self-confidence, then that person will likely have less interest in entrepreneurship (Ayala \& Manzano, 2014). According to Connor (2003), resilience includes several aspects such as emotional regulation, impulse control, optimism, ability to analyze problems, empathy, self-efficacy, achievement. 
An entrepreneur is considered a resilient individual if he is able to face problems, develop and mobilize his / her resources. Resilience is the result of interaction between individuals and their environment, a process that is dynamic and gradual in nature, allowing individuals to learn to gain knowledge, abilities and skills that can help them face difficult times, full of uncertainty based on a positive attitude, with creativity and optimism and rely on the abilities they have. Because basically when someone wants to build a business, what is needed is a sense of confidence in their own abilities if the business they want to build will be successful later.

There have been several previous studies related to the relationship between resilience and quality of life. In Daniele's research (2019), there is a positive relationship between resilience and quality of life in psychotic patients. Research accomplished by Yesim (2015) shows an influence between resilience and quality of life in patients with spinal cord injuries. Whereas with entrepreneurs, if their spirituality is good and increasing and their needs for resilience have been met by the entrepreneur, the quality of life will be guaranteed such as physical health, psychological well-being (body image or appearance, positive feelings, self-esteem, concentration), social relationships (personal relationships), relationship with the environment (financial resources, security, home environment, opportunities for fun activities).

\section{Purpose}

This study aims to determine whether there is a relationship of spirituality to the quality of life (quality of life) in entrepreneurs mediated by resilience.

\section{Method}

\section{Research Design}

This research uses descriptive quantitative method. Quantitative is a systematic approach that makes a clear statement of research objectives, makes specific research questions and hypotheses, is measurable, and observable (Creswell, 2012). In this study, a quantitative approach is used to determine the relationship between spirituality and quality of life which is mediated by resilience.

\section{Universe and Sampling}

As for determining the sample using purposive sampling, the criteria for individual entrepreneurs. The subjects in this study were individuals who had entrepreneurship in Malang with an age range 20-35 years of 100 subjects consist of 76 male and 24 female. In detail, the participants include 21 person aged 20 years old, 19 person aged 24 years old, 21 person aged 28 years old, 20 person aged 32 years old and 19 person aged 35 years old. 
Table 1.

Characteristics of the Subjects $(N=100)$

\begin{tabular}{lll}
\hline Characteristics & $\mathrm{N}$ & $\%$ \\
\hline Gender & 76 & $76 \%$ \\
Male & 24 & $24 \%$ \\
Female & & \\
Age & 21 & $21 \%$ \\
20 years old & 19 & $19 \%$ \\
24 years old & 21 & $21 \%$ \\
28 years old & 20 & $20 \%$ \\
32 years old & 19 & $19 \%$ \\
35 years old & & \\
\hline
\end{tabular}

\section{Data Collection Tools}

The instruments used in this study were The Daily Spiritual Experience Scale spiritual scale, Quality of life scale The Quality of Life Enjoyment and Satisfaction Questionnaire - Short Form (Q-LES-Q-SF) and The Connor-Davidson Resilience Scale (CD-RISC-25)

\section{The Daily Spiritual Experience Scale}

The Daily Spiritual Experience Scale spiritual scale. Developed by Underwood \& Teresi (2002). This scale has 15 items to measure spirituality. Each question has 6 Likert scale answer categories. As for examples of the items include: "I feel grateful for the blessings that have been received", "I feel deep peace or inner harmony".

\section{Quality of life scale The Quality of Life Enjoyment and Satisfaction Questionnaire - Short Form (Q-LES-Q-SF).}

Quality of life scale The Quality of Life Enjoyment and Satisfaction Questionnaire - Short Form (Q-LES-Q-SF). Developed by Endicott, Harrison \& Blumenthal (1993). This scale has 15 items to measure quality of life. Each question has 5 Likert scale answer categories. The sample items include: "how satisfied are you with physical health?", "How satisfied are you with economic status?"

\section{The Connor-Davidson Resilience Scale (CD-RISC-25) Scale}

The Connor-Davidson Resilience Scale (CD-RISC-25). Developed by Kathryn M. Conner and Jonathan R.T. Davidson. (2019). This scale has 25 items to measure resilience. Each question has 4 Likert scale answer categories. The sample items include: "I am able to adapt when changes occur", "I believe I can achieve my goals, even if there are obstacles". 


\section{Sociodemographic Information Form}

The sociodemographic information forms used by participants in this study included age, gender, year of birth and religious beliefs.

\section{Data Collection Process}

The data collection process in this study used questionnaires from The Daily Spiritual Experience Scale spiritual scale, Quality of life scale The Quality of Life Enjoyment and Satisfaction Questionnaire - Short Form (Q-LES-Q-SF) and The Connor-Davidson Resilience Scale (CD-RISC-25). Data was collected from 9 December 2019 to 22 December 2019. Research subjects who are willing to participate are provided a link via email or online to fill in the scale according to the actual subject's circumstances. In this link the researcher conveys that the data information provided is kept confidential, research subjects are allowed to write names using initials. The data that has been collected is then analyzed.

\section{Data Analysis}

This study uses a mediation analysis which is used to answer the question of how variable $\mathrm{X}$ is thought to influence variable $\mathrm{Y}$ through intervention from variable $\mathrm{M}$ (Hayes, 2013). This analysis uses IBM SPSS version 21 with PROCESS macros from Hayes.

\section{Result}

Table 2.

Bivariate Correlations

\begin{tabular}{lcccc}
\hline & Spiritual & Quality of life & Resilience & Reliability \\
\hline Spiritual & & $.897^{* *}$ & $.847^{* *}$ & .848 \\
Quality of life & $.897^{* *}$ & & $.954^{* *}$ & .859 \\
Resilience & $.847^{* *}$ & $964^{* *}$ & & .905 \\
\hline $\mathrm{n}=10{ }^{* * *} p<.01$ & & &
\end{tabular}

Table 2 shows that Spiritual has a positive correlation with Quality of life $\left(\mathrm{r}=.897^{* *}\right.$; $\mathrm{p}<.01)$. Then Spiritual has a positive correlation with resilience $\left(\mathrm{r}=.847^{* *} ; \mathrm{p}<.01\right)$, while Quality of life is positively correlated with resilience $\left(\mathrm{r}=.954^{* *} ; \mathrm{p}<.01\right)$. Resilience has a positive correlation with spiritual $\left(\mathrm{r}=.847^{* *} ; \mathrm{p}<.01\right)$ while resilience has a positive correlation with quality of life $\left(\mathrm{r}=.964^{* *} ; \mathrm{p}<01\right)$. In the present study, alpha internal reliability coefficient was found as .848 for spiritual, .859 for Quality of life and .905 for reliability; and the item total correlations ranged from .306 to. 743 for the scale Quality of Life, item total correlations ranged from .302 to. 791 for the scale resilience and item total correlations ranged from .316 to .691 for the scale spiritual.

The main results of the study showed that spiritual influence significantly affected resilience $\mathrm{a}=1.5623, \mathrm{p}=.000$. Then resilience affects the quality of life significantly $\mathrm{b}=.4013, \mathrm{p}=.0000$. Furthermore, spiritual influence resilience through mediator 
$\mathrm{c}^{\prime}=.3353, \mathrm{p}=.000$. Then obtained an indirect effect of .6269 , direct effect -.3353 , and a total effect of .9622. indirect effect of .6269 in 5000 bootstrap samples and obtained true indirect effects ranging from .5168 to .7337 at $95 \%$ Confidence Interval (CI). So that it can be described a mediation relationship model (4) as follows:

Figure 1.

Mediation relationship model

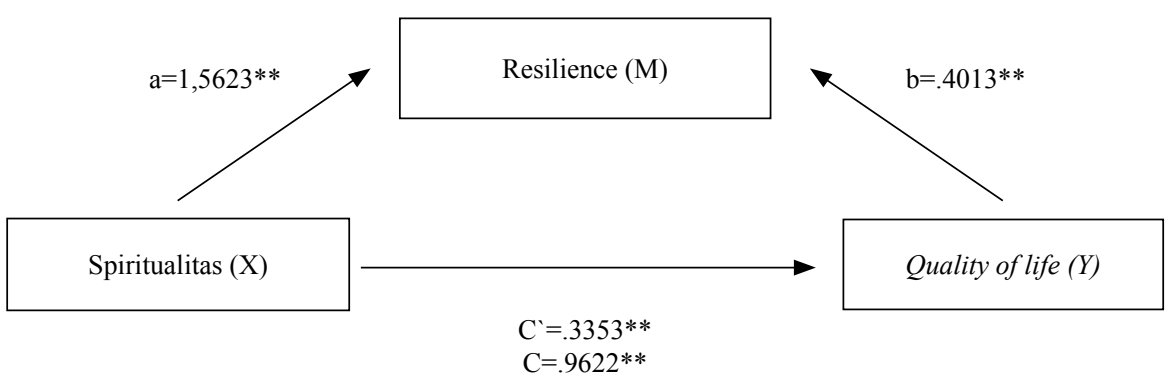

From the mediation model shows that spiritual has a positive relationship with resilience (Line a: $\beta=1.56, p<.000$ ) and resilience is negatively related to quality of life (Line $\mathrm{b}: \beta=.40, \mathrm{p}<.000$ ). As for the path $\mathrm{c}$ shows a significant relationship between spiritual and quality of life $(\beta=.96, p<.000)$, while in the path $\mathrm{c}$ 'shows $(\beta=.33$, $\mathrm{p}=.000$ ) which means that resilience mediates the relationship between spiritual and quality of life with partial mediation.

\section{Discussion}

This study aims to determine the role of resilience in spiritual relationships and quality of life. As explained earlier, the results of this study state that spiritual not only has a direct influence on the quality of life, but also indirectly through resilience. Research on quality of life shows that there are internal factors such as religion (religious) and external factors such as globalization and the country's economic growth (Sandikci et al., 2015). The results of this study focus on internal factors, in this case the spirituality that affects the quality of life in entrepreneurs.

Entrepreneurs still want their business to grow and develop and to improve quality of life, entrepreneurs need spirituality as a means that will make life balanced (Peter $\&$ Schukert, 2014). One that plays a role in running the balance of life is spirituality (Balog, Baker \& Walker, 2013). Balog, Baker \& Walker (2013) research also states that entrepreneurs have a deep meaning to their business activities as a vocation, and the search for deep meaning is influenced spiritually. This is in line with research conducted by Sherman, Randall, and Kauanui (2015), mentioning the importance of spirituality because it can be the main resource and activator, entrepreneurs who have spirituality values in business and practicing religious activities regularly will get happiness, health, pleasure, productivity and better resistance to stress. 
In this study found that spiritual factors can be good predictors and have a mutually supportive relationship when together with other factors. There is already an opinion that shows the preposition of the spirituality variable model with other factors as variables needed by entrepreneurs (Godwin, Neck, \& D'Intino, 2016), namely with resilience. Where the spiritual is able to increase the ability to overcome, survive and even develop in very difficult circumstances, and can adapt to the conditions in the environment, so that someone is still able to achieve the desired quality of life in his life.

Resilience plays a role in improving spirituality by helping someone to achieve a good quality of life. As explained by Aulia (2014), it shows that the more important spirituality is for a person, the greater his ability to overcome the problems at hand. Meanwhile, according to Azwan et al., (2015) individuals with good spirituality will increase coping, optimism, hope, reduce anxiety and support feelings of comfort and calm. This is in line with the characteristics of resilient individuals according to Connor (2003), that resilient individuals will have the ability to achieve a goal in situations of failure and resilient individuals have good confidence in dealing with difficulties and have no doubt in decision making.

That way individuals who have high spirituality show a sense of calm and comfort in life and get the quality of life they want. This is in line with the opinion of Mezeenbroek (2012), that each individual has a purpose in life that arises from a search for meaning that is constantly straightforward which includes a sense of having a mission in life. One of the mission of one's life is to get a good quality of life. In this study, emphasizing the spiritual as a factor that contributes to the quality of life, has a direct relationship with resilience. It is expected that resilience is able to provide a positive picture of coping with a difficult situation, so that it can help individuals deal with pressures that arise in their lives in entrepreneurship. The role of resilience as a mediator emphasizes individual control over the difficulties they face in life as part of meaningful life (Bond \& Flexman, 2006). A meaningful life is to have a quality of life in accordance with the mission and life goals of each individual.

\section{Ethical Statement}

The authors declare that all the steps of the study were carried out in compliance with the Helsinki Declaration. Voluntary participation, anonymity and informed consent were ensured for all participants and there was no experimental manipulation involved in the study. 


\section{References}

Aulia, D, R. (2014). Hubungan Antara Spirirualitas Dengan Meaning Focused Coping Dalam Menghadapi Bencana Pada Masyarakat Banda Aceh. Skripsi Publikasi. Program Studi Psikologi Fakultas Kedokteran Universitas Syiah Kuala Banda Aceh.

Ayala, J., \& Manzano, G. (2014). The resilience of the entrepreneur: Influence on the success of the business. A longitudinal analysis. Journal of Economic Psychology, 42, 126-135.

Azwan., Herlina., \& Karim, D. (2015). Hubungan Sosial Teman Sebaya Dengan Kualitas Hidup Lansia Di Panti Sosial Tresna Werdha. JOM.Vol 2.Nomer 2.Oktober 2015.

Bache, I. (2013). Measuring quality of life for public policy: an idea whose time has come? Agendasetting dynamics in the European Union. Journal of European Public Policy, 20(1), 21-38. DOI: 10.1080/13501763.2012.699658

Baker, D.C. (2003). Studies of the inner life: The impact of spirituality on quality of life. Journal of Quality of Life Research, 12(1), 51-57.

Balog, A. M., Baker, L. T., \& Walker, A.G. (2013). Religiosity and spirituality in entrepreneurship: A review and research agenda. Journal of Management, Spirituality \& Religion. doi: 10.1080/14766086.2013.836127.

Bond, F. W., \& Flaxman, P. E. (2006). The Ability of Psychological Flexibility and Job Control to Predict Learning, Job Performance, and Mental Health. Journal of Organizational Behavior Management, 26, 113-130

Connor, K. M., \& Davidson, J. R. T. (2003). Development of a new resilience scale: The ConnorDavidson Resilience Scale (CD-RISC). Journal of Depression and Anxiety, 18, 76-82.

Creswell, John W. (2012). Planning, Conducting and Evaluating Quantitative and Qualitative Research. Boston: Pearson Education.

Daniele, Zizolfi. (2019). Resilience and recovery style: a retrospective study on associations among personal resources, symptoms, neurocognition, quality of life and psychosocial functioning in psychotic patients

Dash, M., \& Kaur. K. (2012). Youth Entrepreneurship as a Way of Boosting Indian Economic Competitiveness: A Study of Orissa India: International Review of Management and Marketing, 2(1).

Delaney, C. (2005). The spirituality scale development and psychometric testing of holistic instrument to assess the human spiritual dimension. Journal of Holistic Nursing, 23(2), 146-167.

Diener, E., Inglehart, R., \& Tay, L. (2012). Theory and Validity of Life Satisfaction Scales. Social Indicator Research.

Endicott J, Nee J, Harrison W, Blumenthal R. (1993). Quality of Life Enjoyment and Satisfaction Questionnaire: A New Measure. Psychopharmacology Bulletin, 29, 321-326.

Glaeser, E. L., Kerr, S.R., \& Kerr, W. R. (2013). Entrepreneurship and Urban Growth: An Empirical Assessment with Historical Mines. Review of Economics and Statistics, doi:10.1162/ REST_a_00456

Goodwin, J. L., Neck, C. D., \& D’Intino, R.S. (2016). Self-leadership, spirituality, and entrepreneur performance: A conceptual model. Journal of Management, Spirituality \& Religion doi: 10.1080/14766086.2015.1122546

Grine, F., Fares, D., \& Meguellati, A. (2015). Islamic spirituality and entrepreneurship: A case study of women entrepreneurs in Malaysia. The Journal of Happiness \& Well- Being, 3(1), 41-56.

Kasali, R. (2010). Wirausaha Muda Mandiri. Jakarta: Gramedia Pustaka Utama. 
Lorenzini, J. (2015). Subjective Well- Being and Political Participation: A Comparison of Unemployed and Employed Youth. Journal Of Happiness Studies, 16:381, doi:10.1007/s10902014-9514-7

Lu, M., \& Pan, H. (2009). Government- Enterprise Connection Entrepreneur and Private Enterprise Development in China. Peking University Press

M, Rugger (2001). Subjective and Objective Dimensions of Quality of Life in Psychiatric Patients: A Factor Analytical Approach: The South Verona Outcome Project 4. British Journal of Psychiatry, 178(3), 268- 275.

McEwen, W. (2003). Analysis of spirituality contents in nursing textbooks. Journal of Nursing Education, 43(1), 20-30.

Peters, M., \& Schuckert, M. (2014). Tourism entrepreneurs' perception of quality of life: An explorative study. Tourism Analysis, 19, 731-740. DOI: 10.3727/108354214X14146846679484

Qamariah, P. (2016). Strategi humas himpunan pengusaha muda Indonesia dalam menjaring anggota baru di kalangan pengusaha muda di Samarinda. eJournal lmu Komunikasi, 4 (1): 254268, dari http://ejournal. ilkom.fisip-unmul.ac.id/site/wp-content/uploads/2016/03/Jurnal\%20 Putri\%20Qamariah\%20fix\%20(03- 03-16-06-09-22).pdf

Rogala, P. (2014). Evaluation of the Subjective Quality of Life: Polish-German Borderline Case. Paper presented at International Quality Conference, University of Kragujevac.

Roper, N. (2002). Prinsip- prinsip keperawatan. Yogyakarta: Yayasan Essentia Medica.

Ruggeri, M., Bisoffi, G., Fontecedro, L., \& Warner, R. (2001). Subjective and Objective Dimensions of Quality of Life in Psychiatric Patients: A Factor Analytical Approach: The South Verona Outcome Project 4. British Journal of Psychiatry, 178(3), 268-275.

Samli, A. C. (2009). Entrepreneurship economic development and quality of life in third-world countries. Applied Research Quality Life, doi 10.1007/ s11482-009-9056-Z

Sandikci, O., Peterson, M., Ekici, A., \& Simkins, T. (2015). Development and quality of life in Turkey: How globalization, religion, and economic growth influence individual well-being. Journal of Macromarketing, 1-17, doi: 10.1177/0276146715608919

Sherman, C. L., Randall, C., \& Kauanui, S. K. (2015). Are you happy yet? Entrepreneurs' subjective well- being. Journal of Management, Spirituality \& Religion, doi: 10.1080/14766086.2015.1043575

Sirgy, M.J. (2012). The Psychology of Quality of Life Hedonic Well-Being, Life Satisfaction,and Eudaimonia: Second Edition. Social Indicator Research.

Taylor, B. (1997). Earthen Spirituality or Cultural Genocide?: Radical Environmentalism's Appropriation of Native American Spirituality. in Religion, 27(2), 183-215.

Underwood, L. G. \& Teresi, J. (2002). The Daily Spiritual Experience Scale: Development, theoretical description, reliability, exploratory factor analysis, and preliminary construct validity using health related data. Annals of Behavioral Medicine, 24, 22-33.

Yesim, E. (2015). Resilience and quality of life in 161 living kidney donors before ne phrectomy and in the aftermath of donation: A naturalistic single center study.

Young, K.W. (2012). Positive effects of Spirituality on Quality of life for People with Severe Mental Illness. International Journal of Psychosocial Rehabilitation, 6(2), 62-77.

World Health Organization Quality of Life (WHOQOL) (1996) 